\title{
Foreign Law in the Courts: Judicial Notice and Proof
}

\author{
William B. Stern*
}

When rules of conflict of laws point to the applicability of the law of a foreign country, the question arises: how should the court acquire knowledge of the foreign law involved? May or, indeed, should the court take judicial notice of the foreign law? Or should the foreign law be proved by the parties and be disregarded if they fail to comply with their burden of proof?

In former times, when foreign law problems appeared rarely in litigation, a few code sections, implemented by occasional decisions, sufficed to afford a safe guide to courts and litigants. As foreign law has required our increasing respect, nineteenth century ideas of pleading and proof have been put to new tests, and the task of fitting a wealth of problems into a few basic rules which are almost naive in their seeming simplicity has become urgent.

JUDICIAI NOTICE

We state a commonplace when we say that the law of a case is for the court whereas facts must be proved by the parties. This generalization has validity in most judicial systems of the world though not everywhere; but it does not tell us the functions of the court and the parties in bringing out the applicable law and the truth of the facts which are in dispute. Parties may argue the law, but the extent to which a court must consider or disregard these arguments and the other sources which a court may use to supplement its accumulated knowledge differ in various judicial systems. The degree to which the court is in control of taking evidence also differs in many jurisdictions. In some countries, for instance, the parties may merely make an offer of proof while the court decides whether witnesses shall be called. ${ }^{1}$ Here the parties may interrogate the witnesses only after the court has examined them. Nor does the generalizing statement which is the premise of this discussion tell us what is "law" and what are "facts" in a particular judicial system. Indeed, the judicial systems of the world come to various conclusions as to whether foreign law is "law," or a "fact," or "law to be treated procedurally as a fact."

*Foreign Law Librarian, Los Angeles County Law Library.

${ }^{1}$ A detailed comparative study of this problem remains to be written; for general background information see Miller, The Mechanism of Fact Discovery: A Study in Comparative Civil Procedure, 32 Irx. L. REv. 261, 424 (1937). 
Traditionally American courts treated only the law of their own jurisdiction and that of the federal government as law or at least have taken judicial notice only of this law. ${ }^{2}$ Even the law of sister states was "foreign law" of which no judicial notice was taken. Extreme ideas of state sovereignty were the reason for this narrow concept of "law" or judicial knowledge of law. ${ }^{3}$ From a purely practical point of view we might add that legal research and the status of law libraries was such as to make acquaintance with the law of sister states always difficult and at times almost impossible. In California, for example, a court will take judicial notice of the law of sister states only since $1927,{ }^{4}$ but oral evidence of the unwritten law of sister states apparently remains permissive. ${ }^{5}$

By contrast, the law of foreign countries is not subject to judicial notice under the traditional view to which most American states, including California, continue to adhere. This rule, however, is subject to several qualifications or exceptions. The law of an antecedent foreign government is deemed to be the law of its successor government to the extent to which the old law has created property rights, affected status or continues to be in force; the antecedent law is subject to judicial notice to this extent. ${ }^{6} \mathrm{~A}$ court will also take judicial notice of imcidents of foreign law which have become a part of the political history of the world. ${ }^{7}$ Thus a court may take judicial notice of various policies of the National Socialist regime ${ }^{8}$ or of the Communist character of the Romamian government in $1949 ;{ }^{\circ}$ judicial notice of facts which form a part of the political history of the world will rarely suffice to determine the issues of a case, but it is well suited to supply the background knowledge required to understand the issues of foreign law which may be at stake. Finally, a particular statute may provide for taking judicial notice of facts not usually so noticed..$^{10}$

II

PROOF OF FOREIGN LAW

It has previously been indicated that the traditional common law procedure and practice is to treat foreign law as if it were a fact. ${ }^{11}$ This view

25 WIGMORE, EVIDENCE $§ 2573$ (2d ed. 1923).

39 Id. § 2573 (3d ed. 1940).

4 Cal. Code Crv. Proc. \$ 1875 (3).

5 Id. § 1902; cf. Duluz v. Alaska Packers Ass'n, 177 Cal. 465, 170 Pac. 1133 (1918); Estate of Keig, 59 Cal. App. 2d 812, 140 P.2d 163 (1943).

6 Ohm v. San Francisco, 92 Cal. 437, 28 Pac. 580 (1891); Payne \& Dewey v. Treadwell, 16 Cal. 220 (1860) ; Holliday v. West, 6 Cal. 519 (1856); accord, Wells v. Stout, 9 Cal. 479 (1858).

7 E.g., Cat. Code Crv. Proc. \$ 1875(8).

8 In re Estate of Krachler, 199 Ore. 448, 263 P.2d 769 (1953). It is interesting to note that the court stated the sources on which it relied in taking judicial notice of these policies.

9 Estate of Kennedy, 106 Cal. App. 2d 621, 235 P.2d 837 (1951).

${ }^{10}$ See, e.g., CAI. Corp. CODE $\$ 6602$. The purport and effect of this section are not clear and as yet have not been defined by appellate courts as far as judicial notice of foreign law is concerned.

11 Sussex Peerage Case, 11 Cl. \& Fin. 85, 8 Eng. Rep. 1034 (H.X. 1844). 
may be based on the theoretical premise that anything which is not deemed to be law must be a fact. One therefore frequently encounters the statement that foreign law is a fact, although it would be more correct to say that foreign law is treated like a fact.

If foreign law is deemed to be a fact or is treated like a fact, the logical consequences would be that:

1. Foreign law must be pleaded like a fact;

2. Foreign law must be proved like a fact;

3. Foreign law questions go to the jury in appropriate cases;

4. If facts are not considered on appeal, foreign law cannot be considered on appeal; and

5. The holding of a court on questions of foreign law in one case is not evidence in other cases involving the same foreign law problems; and holdings of appellate courts on foreign law do not have the force of stare decisis.

All these views have been taken in the long history of common law and modern code procedure. But the apphication of these views has undergone legislative or judicial change in many respects in most jurisdictions.

A.

\section{Consequences of Treating Foreign Law as Fact}

\section{Foreign Law Must be Pleaded Like a Fact}

When foreign law must be pleaded as a fact, a complaint which fails to comply with this rule is subject to demurrer..$^{12}$ Proof of foreign law is precluded without prior pleading. ${ }^{13}$ Application of this rule has lead to the dismissal of actions when the foreign law was not pleaded although justice may have been fully in favor of the plaintiff. ${ }^{14}$ Dismissals are, however, usually avoided by presuming or assuming the foreign law to be the same as that of the domestic jurisdiction; ${ }^{\mathbf{1 5}}$ they might well be avoided by pointing out the need of pleading the foreign law in pre-trial proceedings or upon demurrer.

12 The Baja California, 45 F. Supp. 519 (S.D. Cal. 1942), af'd sub nom. Republic of Mexico v. Hoffman, 324 U.S. 30 (1945).

13 Ibid.

14 Cuba R.R. v. Crosby, 222 U.S. 473 (1912). In this case a railroad employee suffered an injury in Cuba while working with machinery the defective condition of which was constructively known to the employer. The decision has frequently been criticized as arriving at an "unjust" result. The criticism may not be justified as in inany civil law systems an employee does not have a cause of action in tort against his employer-a principle with which Justice Holmes may have been extrajudicially familiar. For criticism of the Crosby rule see ScHLESINGER, Comparattve Foreign LAW 121 (1950); Nussbaum, The Problem of Proving Foreign Lav, 50 YALE L.J. 1018, 1039 (1941).

15164 East Seventy-Second Street Corp. v. Ismay, 65 Cal. App. 2d 574, 151 P.2d 29 (1944). Further discussion of this technique will be found in the text following note 41 infra. 
It is assumed by most writers that foreign written law need not be pleaded in haec verba $a^{16}$ and that a pleading suffices if it contains a substantial statement of the foreign written or unwritten law on which the pleader intends to rely. ${ }^{17}$ It would also seem unnecessary to state in the pleading whether the party intends to rely on written or unwritten foreign law or perhaps on an interpretation of written foreign law. Pleadings couched in general language have the advantage of enabling parties to adduce at the trial evidence on details of foreign law which may not be known at the pleading stage or which receive their importance only by reason of the position which the defendant may subsequently take. The need to go into general principles and definitions of the foreign law may become apparent only during the trial; also, detailed pleadings on foreign law may exceed the ultimate facts and may amount to pleading of the evidence. On the other hand, the pleading should suffice to enable the adversary to understand the issues of foreign law on which the pleader intends to rely. Trial courts in California seem to be satisfied with general statements of foreign law which amount to pleading the effect of the foreign law..$^{18}$

\section{Foreign Law Must be Proved Like a Fac: $:^{10}$}

The proposition that foreign law must be proved like a fact has led to the English view that foreign law must be proved by witnesses. This view is not held in most American jurisdictions where written foreign law may be proved by suitable copies whereas unwritten foreign law is proved by expert witnesses. In some jurisdictions unwritten foreign law also may be

${ }^{16}$ See Sommerich \& Busch, The Expert Witness and the Proof of Foreign Law, 38 ConNEIx L.Q. 125,136 (1953).

17 Moe v. Shaffer, 150 Minn. 114, 184 N.W. 785 (1921).

18 E.g., that under the law of the Mexican State of $X$ a marriage of minors is subject to annulment unless those exercising parental control have expressly or impliedly agreed to the marriage and provided that those exercising parental control over the minor bring the action within 30 days after having received knowledge of the marriage. The question of how foreign law should be pleaded is not without doubt. The above considerations are substantially in accord with Sommerich \& Busch, The Expert Witness and the Proof of Foreign Law, 38 CorNEIT L.Q. 125 (1953).

McKenzie \& Sarabia, The Pleading and Proof of Alien Law, 30 Tux. L. REv, 353 (1956), suggest that more detailed pleadings of foreign law are preferable. Pleadings of the nature suggested by these authors require, however, full acquaintance of the pleader with the details of foreign law at the pleading stage, whereas, as a matter of practical experience, most attorneys acquire their detailed knowledge of foreign law (as contrasted with knowledge of the general issues) only at the time of trial when the expert witnesses are examined.

When foreign law is pleaded by reference to a statute or other writing, the defendant in California may avail himself of lis right to demand production of such writing in discovery proceedings. See CAL. Code Civ. Proc. $\$ 1000$.

19 For details concerning the proof of foreign law see text following note 60 infra. The question whether parties may stipulate to the applicablity of dounestic law is beyond the scope of this investigation. 
proved by decisions of foreign courts, or at least the highest foreign courts, or by treatises of learned men; while in others the foreign law, written or unwritten, may be proved by certificates of properly qualified foreign government authorities, or parties may under certain circumstances stipulate that domestic law shall govern the issues of the case.

\section{Foreign Law Before the Jury}

Under the traditional common-law view questions of foreign law go to the jury. This view is still held in Califorma ${ }^{20}$ when the construction and interpretation of a foreign statute is controversial or unwritten foreign law is involved and the character of the foreign law issues invites the testimony of experts. ${ }^{21}$ The latter qualification of the general rule raises the question whether in the rare cases in which merely the application of a foreign statute, unincumbered by construction or interpretation, is involved the foreign law issues are to be decided by the judge.

In the majority of states the common law view has been rejected and all questions of foreign law are decided by the judge..$^{22}$ The majority view may be justified theoretically on the ground that foreign law, once pleaded and proved, assumes the character of "law" and so becomes subject to determination by the judge even though its applicability, construction and interpretation may be a controversial issue. The majority view has been stated by Wigmore to be the "sound view."23 Under the Uniform Judicial Notice of Foreign Law Act, ${ }^{24}$ adopted in twenty-five states and Hawaii, foreign law, though deemed a matter of fact, is an issue for the judge. The purpose of the act is stated in the commissioners' note as follows: ${ }^{25}$

[W] do want to make the foreign law determinable by the judge, not the jury, thus changing the absurd old common law.

When questions of foreign law do go to the jury, the admonition in Peaple v. Tufts ${ }^{26}$ that the judge should assist the jury in reaching a just conclusion by analyzing the testimony and showing its possible application to the theories of the respective parties is fully justified.

\section{Foreign Law on Appeal}

Questions on foreign law issues reach an appellate court which deals nerely with questions of law only when the trial court has not made find-

20 People v. Tufts, 167 Cal. 266, 139 Pac. 78 (1914). This was a criminal case involving the law of a sister state prior to 1927 , i.e., at a time when the law of a sister state was deemed to involve questions of fact.

21 Hawi Mill \& Plantation Co. v. Finn, 82 Cal. App. 255, 255 Pac. 543 (1927).

22 See authorities cited at notes 23 and 24 infra.

239 WIGMORE, EVIDENCE § 2558 (3d ed. 1940).

24 UNIFORAT JUDICIAI NOTICE OF FOREIGN LAW ACT $\$ 5$.

259 U.L.A. 408 (1951).

26167 Cal. 266, 270, 139 Pac. 78, 80 (1914). 
ings on foreign law or when it is urged that relevant evidence was prejudicially excluded, ${ }^{27}$ that the evidence on foreign law is not as a matter of law sufficient to support the findings, ${ }^{28}$ or that the finding of the trial court is not supported by substantial evidence. ${ }^{29}$ Otherwise the determination of unwritten foreign law is a question of fact for the trial court; ${ }^{30}$ and its determination of the issues concerning the existence, translation, interpretation, and effect of foreign witten law will not, when based on conflicting evidence, be disturbed. ${ }^{31}$ Occasionally an appellate court will reverse the decision of the trial court and suggest the clarification of foreign law points when testiniony on foreign law is deemed confused or insufficient; ${ }^{82}$ but the ruling of the trial court that an expert witness is qualified rests within its sound discretion and will not be disturbed where there is no showing of a clear abuse of this discretion. ${ }^{33}$ When expert witnesses contradict each other, the decision depends on which particular expert the trial court choses to believe. ${ }^{84}$

On the other hand, where questions of fact reach the appellate court, it is not bound by the findings of the trial court on conflicting questions of foreign law..$^{35}$ Doubtless in some jurisdictions appellate courts have a "propensity ... to apply their own logic and reasoning in arriving at the law, rather than limiting these processes to examination of the trial court's conclusion."

\section{No Effect of Appellate Holdings on Other Cases}

The treatment of foreign law as a fact for purposes of pleading, proof, and appeal deprives the holdings on foreign law of one court from becoming rules which control the decisions of other courts under the rule of stare decisis. ${ }^{37}$ Nor does the determination of a foreign law issue in one case become

27 Estate of Peters, 110 Cal. App. 2d 723, 244 P.2d 88 (1952).

28 Estate of Arbulich, 41 Cal. 2d 86, 257 P.2d 433 (1953).

29 Estate of Schluttig, 36 Cal. 2d 416, 224 P.2d 695 (1950); Estate of Cleland, 119 Cal. App. 2d 18, 258 P.2d 1097 (1953); Estate of Reihs, 102 Cal. App. 2d 260, 227 P.2d 564 (1951); Estate of Johnson, 100 Cal. App. 2d 73, 223 P.2d 105 (1950).

30 Pintel v. K.N.H. Mohammed \& Bros., 107 Cal. App. 2d 328, 237 P.2d 315 (1951); Hawl Mill \& Plantation Co. v. Finn, 82 Cal. App. 255, 255 Pac. 543 (1927).

31 Estate of Schluttig, 36 Cal. 2d 416, 224 P.2d 695 (1950); Estate of Leefers, 127 Cal. App. 2d 550, 274 P.2d 239 (1954); Logan v. Forster, 114 Cal. App. 2d 587, 250 P.2d 730 (1952); Estate of Miller, 104 Cal. App. 2d 1, 230 P.2d 667 (1951); Estate of Reihs, 102 Cal. App. 2d 260, 227 P.2d 564 (1951).

32 Henderson v. Drake, 118 Cal. App. 2d 777, 258 P. 2d 879 (1953).

38 Estate of Johnson, 100 Cal. App. 2d 73, 223 P.2d 105 (1950).

84 Estate of Leefers, 127 Cal. App. 2d 550, 274 P.2d 239 (1954); Estate of Miller, 104 Cal. App. 2d 1, 230 P.2d 667 (1951).

35 In re Estate of Krachler, 199 Ore. 448, 263 P.2d 769 (1953).

38 McKenzie \& Sarabia, The Pleadng and Proof of Alien Law, 30 Tor. L. Rev. 353, 356 (1956).

37 See note 38 infra. 
res judicata in other cases involving the same question. ${ }^{38}$ This view is practically as well as theoretically justified since the proof of foreign law may have been insufficient in the earlier case, the foreign law may not have been fully available in earlier litigation, or because courts may disagree concerning the credibility of witnesses or the value of their conclusions. ${ }^{39}$ It is therefore entirely possible that controversial issues of foreign law may cause divergent decisions of courts on the same foreign law subject. On the other hand, the present rule may lead to an immense repetition of the same expert testimony even in uncontested cases ${ }^{40}$ - a situation whicl invites legislative change.

B.

\section{Proof of Foreign Law Treated as a Fact}

\section{The Presumption that Foreign Law is the Same as Domestic Law}

The dismissal of actions in which foreign law is not pleaded or proved is usually avoided by assuming or presuming the particular foreign law to be the same as the domestic law. ${ }^{41}$ In some jurisdictions statutes have been enacted under which foreign law is deemed prima facie the same as the domestic law. ${ }^{42}$ Whereas the presumption merely shifts the burden of going forward, the latter rule shifts the burden of proof. ${ }^{48}$

The presumption that foreign law is the same as domestic law when the former is not pleaded and proved has been applied in California in numerous cases. ${ }^{44}$ The presumption also is applied in California in cases in which the domestic law is statutory in origin; however, if it is assumed that a statute is of such a specialized nature that it may not have its foreign counter-

88 See note 34 suprc.

89 This was the case in the litigation of reciprocal riglits of inheritance with National Socialist Germany. In Estate of Miller, 104 Cal. App. 2d 1, 230 P.2d 66 ' (1951), the court took umbrage at the decision in Estate of Schluttig, 36 Cal. 2d 416, 224 P.2d 695 (1950), because more evidence on National Socialist law was available in the Miller case than in the Schluttig case. Still later, another court to wbich further evidence on National Socialist law was presented held in contradiction to the findings in the Miller case. Estate of Leefers, $127 \mathrm{Cal}$. App. 2d 550, 274 P.2d 239 (1954). These cases were extensively reviewed in In re Estate of Krachler, 199 Ore. 448, 263 P.2d 769 (1953), where the court's findings approached those of the court in the Leefers case.

40 See text following note 140 infra.

41 Norris v. Harris, 15 Cal. 226 (1860), establishing the rule in California; see cases cited at note 44 infra. Concerning this presumption in general see Kales, Presumption of the For. eign Law, 19 HaRv. L. Rev. 401 (1906).

42 See Wachtell, Proof of Foreign Law in American Courts, 69 U.S.L. REv. 526, 580, 581 (1935).

43 See Kales, Presumption of the Foreign Law, 19 HaRv. L. Rev. 401 (1906).

14 E.g., Rediker v. Rediker, 35 Cal. 2d 796, 221 P.2d 1 (1951); deYoung v. deYoung, 27 Cal. 2d 521, 165 P.2d 457 (1946); Glasband v. Hussong, 146 A.C.A. 728, 304 P.2d 225 (1956); Louknitsky v. Louknitsky, 123 Cal. App. 2d 406, 266 P.2d 910 (1954), 42 CALIF. L. REv. 701; Silveyra v. Harper, 82 Cal. App. 2d 761, 187 P.2d 83 (1947); Perkins v. Benguet Consol. Mining Co., 55 Cal. App. 2d 720, 132 P.2d 70 (1942). 
part or when a statutory penalty is involved, the presumption will not be applied.$^{45}$ Of course the presumption does not apply when a statute inakes the existence of a right dependent on the existence of a similar right in a foreign country and casts the burden of proving the foreign law on one of the parties. ${ }^{48}$ The presumption that foreign law is the same as domestic law has even been applied when the foreign law may have been silent on the point involved ${ }^{47}$ or the domestic law not yet clearly established. ${ }^{48}$

On the other hand, when a plaintiff urges that the law of a foreign country should not be apphied because that country is an "uncivilized" country, he must prove the law of the "uncivilized" country before the court will decide which law is applicable. ${ }^{49}$

The far reaching effect of the presumption has caused various suggestions directed toward a limitation of its application when confusion concerning status and property rights miglit arise. Professor Nussbaum has suggested: ${ }^{50}$

It hardly need be said that the foreign law governing divorce, or annulment of marriage, cannot be replaced by the lex fori merely because of failure to plead or to ascertain the foreign law. The same can probably be said of property litigation originating in familial and inheritance situations.

California courts, however, have applied the presumption in cases involving the validity of divorces ${ }^{51}$ and marital property rights. ${ }^{62}$

It has also been urged that in order to prevent the presumption from assuming a ficticious character it should be applied only when there is a strong possibility that the foreign law is actually the same as the domestic

45 Ryan v. North Alaska Salmon Co., 153 Cal. 438, 95 Pac. 862 (1908); Klaffki v. Kaufman, 52 Cal. App. 48, 198 Pac. 36 (1921).

${ }^{46}$ See, e.g., CAL. ProB. CoDE $\$ \S 259-59.2$. However, in cases involving reciprocal rights of inheritance the presumption that foreign law of an earlier date reunains the same, even under a later Communist regime, applies. Estate of Kennedy, 106 Cal. App. 2d 621, 235 P.2d 837 (1951). The presunption that foreign law of an earlier date remains the same also applies in the case of a change of de facto sovereignty. Cobb v. Umited States, 191 F.2d 604 (9th Cir. 1951) (Okinawa).

47 Christ v. Superior Court, 211 Cal. 593, 296 Pac. 612 (1931) (semble).

48 See Blochman Commercial \& Sav. Bank v. Ketchain, 36 Cal. App. 284, 171 Pac. 1084 (1918).

49 Walton v. Arabian Am. Oil Co., 233 F.2d 541 (2d Cir. 1956).

${ }^{0} 0$ Nussbaum, The Problem of Proving Foreign Law, 50 Yare L.J. 1018, 1041 (1941).

61 Rediker v. Rediker, 35 Cal. 2d 796, 221 P.2d 1 (1951); deYoung v. deYoung, 27 Cal. 2d 521, 165 P.2d 45\% (1946).

52 Louknitsky v. Louknitsky, 123 Cal. App. 2d 406, 266 P.2d 910 (1954). Here the court presumed that the law of China and Hong Kong concerning marital property rights was the same as that of California. This decision has caused one writer to suggest that a court should be entitled to take judicial notice of foreign law rather than be hound to apply the presumption. 42 CArrF. L. REv. 701 (1954). Actually, lowever, the decision in this case worked "substantial justice," as the Chimese Civil Code in force since 1931 provides for a certain type of commurity property. CHINESE CIV. CoDE, bk. IV, art. 1016. 
law. ${ }^{53}$ Moreover, it has been suggested that the presumption should apply only when the law of the foreign jurisdiction involved is based on the same common-law heritage as that of American jurisdictions and employs the Enghish language. ${ }^{54}$

While it has been said that the presumption may often lead to "unreasonable" results, ${ }^{65}$ we may agree with Nussbaum ${ }^{56}$ that the application of the presumption works "substantial justice" in many cases. Parties may avoid its application by pleading and proving the foreign law, but the presumption permits even the adjudication of cases in which the foreign law is unknown and cannot be brought into experience. ${ }^{57}$ Whether the presumption should be applied in such circumstances has been discussed in the European literature from time to time; some authors present the view that in such cases the complaint should be dismissed, whereas others favor application of the domestic law when it would serve to avoid a miscarriage of justice. ${ }^{58}$ Other authors have suggested that in such cases the court should apply the law of a legal system to which that of the unknown foreign law is related by a common heritage. ${ }^{60}$ The application of this theory may have some strange results: a court unable to ascertain the Norwegian or Icelandic law on a given subject might apply Damish law, to which the Norwegian and Icelandic law bear a general historical resemblance, although it is known that the laws of these three jurisdictions differ in many respects. Similarly, a court unable to determine the Soviet Romanian law might apply the Soviet Russian law although identification of the Romanian law with the Soviet law does not correspond to the historical facts.

\section{General Problems of Proof of Foreign Law}

Under the common law as administered in England an expert must always be called to prove the foreign law.$^{60}$ American jurisdictions, relying

63 See Kales, Presumption of the Foreign Law, 19 Harv. L. Rev. 401, 407 (1906); von Moschzisker, Presumption as to Foreign Law, 11 MINN. L. REv. 1, 11 (1926).

54 See, e.g., 9 WIGMORE, Evidence \$2536 (3d ed. 1940). California courts have even applied the presumption to the law of England although English law has undergone considerable changes in the course of years and some of its former basic ideas are almost irrecognizable in later enactments. See Murphy v. Murphy, 145 Cal. 482, 78 Pac. 1053 (1904); Wickersham v. Johnston, 104 Cal. 407, 38 Pac. 89 (1894).

65 Leary v. Gledhill, 8 N.J. 260, 84 A.2d 725 (1951).

68 Nussbaum, The Problem of Proving Foreign Lavs, 50 YAre L.J. 1018, 1039 (1941).

${ }^{67}$ At times subscriptions cannot be placed to the official gazettes and reports of decisions of Soviet dominated countries. Distribution of the Hungarian official gazette was restricted to high government officials for several years. In the Romanian official gazette the publication of laws which were to be kept secret was omitted for some time. For several years the Chinese Communist regime has failed to publish its laws and decrees in an official gazette or in any other organized manner.

68 Authorities on these views are collected in RIEZLER, INTERNATIONALES ZiviLPRozessRECET 497 (1949).

69 See Rapee, Internationales Privatrecet 119 (4th ed. 1955).

00 Fos the method of proof of foreign law in England see Hirschfeld, Proof of Foreign Law, 11 L.Q. REv. 241 (1895). 
on Story's statement of the common law ${ }^{61}$ or on the Field Codes, divide foreign law into written law which may be evidenced by copies thereof and unwritten law which, as a rule, must be proved by expert witnesses. ${ }^{03}$

The division of law into written and unwritten law appears at first glance capable of intelligent application, but in practice it helps little in the determination of foreign law disputes. Search after the meaning of written law, in fact the investigation of whether a written law was in force at a particular time and place, so frequently involves points of unwritten law that there are few cases in which the presentation of the written law suffices. Making the written law subject only to documentary proof deprives courts of the inspection of other written sources of foreign law unless these latter sources are admissible under the provisions concerning proof of the unwritten law. In addition, there may be at issue foreign law for which the sources of law of the country involved do not provide an answer. ${ }^{0.3}$

\section{Proof of Written Foreign Law}

The manner in which written law may be presented is usually prescribed by statutes. ${ }^{64}$ The mode of producing certified or authenticated copies of the foreign written law has proved too cunbersome, and most statutes admit "as evidence" of foreign law either official publications or private works proved to be commonly recognized in the foreign courts. Some difficulty is encountered by these statutes since rarely is "evidence" of domestic law taken or are books purporting to contain written domestic law formally "admitted" as evidence. ${ }^{68}$

Translations of foreign written law should be furnished whenever for-

61 StORY, CoNFLICT OF LAWS $\$ \$ 641-42$ (1834).

82 The terms "written" and "unwritten law" are defined in CaI. Code CIv. PRoc. \$\$ 1896, 1899. For a definition of "unwritten law" see also Wachtell, Proof of Foreign Law in American Courts, 69 U.S.L. Rev. 526, 537 (1935). The Field Codes omit Story's statement that witnesses may also testify on foreign customs and usages, presumably because these customs and usages are a part of the unwritten law although not mentioned in the Code definition.

63 See text at note 86 infra.

64 See, e.g., Cat. Code Crv. Proc. $\$ \S 1900,1901,1918(4)$.

65 E.g., id. \& 1900; see 5 WrGMrore, EVIDENCE \& 1684 (3d ed. 1940).

68 The fact that the written foreign law is frequently produced from volumes owned by private individuals or private or public libraries bas led to the general practice of introducing such volumes only by reference or of accepting typewritten or photo-reproduced copics of the pertinent parts thereof or of dispensing with the imtroduction of such volumes completely when translations are offered into evidence. If these translations are found in privately or publicly owned books, typewritten or photo-reproduced copies of the pertinent parts thereof should be introduced into evidence. Translations which are made by expert witnesses or other translators may be introduced into evidence either in writing or by reading them into the record. The latter practice is not only of doubtful validity when the foreign language copy is not introduced into evidence, but is likely to produce the frequently criticized result that foreign law may be hard to understand. It would seem advisable to prepare a suffeient number of copics of foreign written laws and translations thereof so that all parties receive a copy. 
eign written law is in issue as most statutes do not provide for judicial notice of foreign languages. In addition, there may be a constitutional mandate requiring English language translations. ${ }^{67}$ The preparation of adequate translations of foreign written law and court reports as well as foreign treatises and articles is more difficult and time-consuming than is frequently recognized. A translator of such materials must not only be familiar with the foreign language involved, its differentiations, shadings and nuances, but he must also be familiar with the foreign legal terminology and other particularities of the foreigu legal language. ${ }^{68} \mathrm{He}$ must know, for instance, that punctuation is not a part of English statutes and be aware that corrections of statutory texts published in Mexican official gazettes are frequently made in subsequent issues. He must also be familiar with the words and plrases used in English legal language and avoid the use of English language similes which do not convey the proper meaning of the translated text. ${ }^{69}$

The preceding considerations show clearly the necessity for an expert witness to give all possible attention to the correct English rendition of foreign legal language. He is likely to run into trouble if he is not thoroughly familiar with English or has an insufficient understanding of English legal terminology. He will attenpt to render a smooth-reading transla-

67 E.g. Car. Consr. art. 4, § 24 provides that judicial proceedings shall be held in the English language. The application of this section to the presentation of foreign written law has not been judicially appraised.

os See Gutrermge, Comparative Law 49 (2d ed. 1949). Cases are mentioned in the literature in which the Spanish word "actualmente" was translated as "actually" whereas it meant "presently" and the German word "beiwohnen" as "to reside" whereas it meant "to cohabit."

Translations should be offered together with the testimony of an expert witness or other competent translator to the effect that he is familiar with the English and the particular foreign language, that he has made the translations or examined them and compared them with the foreign language documents from which they have been made, and that the translations are full, true and correct translations of the translated materials. The translating witness should be permitted to explain why he has translated certain words in the manner he did and what in his opinion the English words which he used mean in the particular context.

69 E.g., "custody" should not be translated as "care" or "prescription" as "limitation." A translator should translate as literally as possible and avoid interpreting while translating. Literal translations may read clumsily, but production of the text of the foreign law should be separated from opinion evidence. Sometimes foreign legal words and phrases cannot be translated as equivalents in English legal language are lacking. In such cases the translator should use an English simile and orally explain the meaning of the foreign term. The preceding statements make it quite plausible that foreign law experts may disagree on the proper translation of the foreign law text concerning which they testify. A witness may be unfamiliar with the meaning given to a foreign or domestic term involved or may fail to see the significance which the words used by him may have; he may fail to realize that a foreign legislator may not have given sufficient attention to the phraseology of a statute or decree, thereby inviting conflicting views concerning the meaning of a term. Most disputes about legal translations, however, are caused by the fact that many translators are inclined to interpret while translating and to use without explanation English similes which do not convey the proper meaning. 
tion, but better fail in this endeavor lest he interprete rather than translate. It has been suggested that the final draft of the translation be completed by a person who is familiar only with English; ${ }^{70}$ this suggestion not only prevents the expert from testifying to the accuracy of the translation, but is likely to produce a meaning which differs from the original text.

The difficulty and expense of translating has encouraged the use of printed or otherwise published translations, sometimes without even accompanying evidence of their correctness. ${ }^{71}$ Doubtless, published translations of foreign constitutions, codes, statutes, and decrees are most helpful and in most instances not subject to criticism, but they should be used only with the understanding that they reflect the text of the written law in force at a particular time. Some of these published translations may incorporate interpretative notions of the translator or give evidence that they were made by persons who do not have a sufficient understanding of the foreign or domestic legal terminology involved. At times, such translations may contain serious errors. ${ }^{72}$

\section{Unwritten Foreign Law}

Unwritten foreign law may be proved by the oral testimony of expert witnesses. ${ }^{73}$ The testimony may include the unwritten law as collected from the reported decisions of the foreign courts and the treatises of learned men; ${ }^{74}$ it may also be proved by printed and published books of reports of decisions of the courts of foreign countries. ${ }^{75}$ By their wording these rules refer not only to decisions of the highest courts, but also to those of lower courts. The question presents itself whether reports of decisions of foreign courts are admissible although the rule of stare decisis is not operative under the law of the foreign country. It would seem that a full presentation

${ }^{70}$ McKenzie \& Sarabia, The Pleading and Proof of Alien Law, 30 Tvr. L. Rev. 353, 367 (1956).

71 For a survey of some of these translations see Szladits, Note on Translations of Forcign Civil and Commercial Codes, 3 Axr. J. Comp. L. 67 (1954).

72 In a widely used translation of a Mexican statute the word "not" was omitted at one place. Caution also may be justified when the translator fails to indicate whether he translated from an official text or a text commonly recognized in the courts of the forcign country involved; or he states that he has based his translation on a foreign text which is not official and not commonly recognized in the courts of the country whose laws he translates. When doubts arise concerning the correctness of the translation, the published translations should be compared with the official foreign text or texts commonly recognized in the courts of the foreign country and inquiry made of experts on foreign law concerning the sufficiency and correctness of the translation. At times, a comparison of several translactions of the same text may prove helpful.

78 See, e.g., CaI. CODE Crv. Proc. \$ 1902.

74 See, e.g., id. § 1899.

75 See, e.g., id. § 1902. 
of the foreign law may require consideration of these decisions although under certain circumstances little weight may attach to them. ${ }^{76}$

The division of foreign law into written and unwritten law and the methods for their proof are premised on the assumption that foreign countries have the same sources of law as English and American jurisdictions. However, each country determines for itself its sources of law; therefore, if, as in France, treatises and articles in legal periodicals are deemed a source of law, they should be admitted into evidence here when French law is drawn in question. Similarly, when by German practice commentaries on codes and statutes have become sources of the German law and as such are frequently used by German courts, they should be admitted into evidence in American courts when the presentation of German legal problems so requires. ${ }^{77}$ California courts have permitted the introduction of such commentaries when they were sources of foreign law. ${ }^{78}$ Textbooks, monographs, commentaries, treatises, articles in legal periodicals, and dictionaries are freely admissible in England, ${ }^{79}$ where foreign law is proved as a fact, and in New York, which follows judicial notice ideas. ${ }^{80}$

It is open to question whether foreign treatises and the like may be introduced into evidence as forming the basis of or supporting the witness' opinion rather than as sources of the foreign law. ${ }^{81}$

\section{Written Law Supplemented by Unweritten Law}

Experience has imdicated that there are very few cases which involve only written law. Frequently, expert testimony is required concerning intimately related questions: was the written law at issue in force at the crucial time and place, or was it suporseded by later legislation or declared unconstitutional or ineffective for other reasons; is the written law applicable to the facts at hand and is it all the law on the subject; has it received a special construction in the foreign jurisdiction or nust it be construed in the light of foreign legal terminology and rules of construction? As Wig-

76 Wigmore suggests that foreign court reports should be admissible for proof of unwritten foreign law provided that they are used in the foreign jurisdiction "among the" legal "profession." 6 WIGMORE, EvIDENCE $\$ 1703$ (3d ed. 1940).

77 See id $\$ 1697$.

78 Estate of Leefers, 127 Cal. App. 2d 550, 274 P.2d 239 (1954). In Birch v. Birch, 136 CaI. App. 2d 615, 289 P.2d 53 (1955), the court held textbooks in English or French on Chinese family law not admissible as they are not official documents nor laws, but merely the expression of the author's opinion as to what the Chmese law was. Apparently there was no proof that the textbooks presented were used in Chinese courts as sources of Chinese law.

70 See 13 HalsbuRY, Laws of ENGLAND 615 (2d ed. 1934).

80 See Nussbaum, Proof of Foreign Law in New York: A Proposed Amendment, 57 Colusc. L. REv. 348 (1957) ; Sommerich \& Busch, The Expert Witness and the Proof of Foreign Lan, 38 Corkenc L.Q. 125, 154 (1953).

81 See note 140 infra. 
more notes, ${ }^{82}$ in the usual case a question of foreign law is not answered solely by the production of a copy of the statute; one must consider the state of the law at a given time and how custom or judicial precedent has affected the statute. To consider the constitutionality, effect and use of a statute without accompanying expert testimony may be misleading and ignore material elements. For these reasons Califorma courts have frequently permitted the use of expert testimony on issues involving foreign written law. ${ }^{83}$ In Estate of Schluttig ${ }^{84}$ the court stated: ${ }^{85}$

[T] he issue before the superior court required a consideration not only of the existence of the foreign statutes but a finding as to their effect based upon the translation of them and their practical application by the courts of the respective countries. The parties did not agree as to the correct translation of the statutes and each stressed uncertainties and ambiguities which required explanation. Moreover, it was shown that the right to inherit in the foreign countries depended upon certain policies of the Nazi regime. Upon all these subjects, both parties presented considerable testimony by experts.

....

Considering the nature of the evidence before the trial court, it is clear that the issue to be determined involved questions as to the existence, translation, interpretation and effect of the laws of Germany and Austria. Upon these subjects, the superior court heard highly conflicting testimony by experts upon the laws of those countries and their application under given circumstances.

A peculiar need for elasticity in the proof of foreign law by expert witnesses arises over questions for which the sources of the particular law do not provide an answer. For instance, a European country may have neither statutory or case law nor a statement by a text writer or commentator on the subject of whether an alien may inherit under the same terms and conditions as a citizen. ${ }^{86}$ In such cases the witness should indicate this gap to the court and testify to the way in which a foreign court would fill the gap. $\mathrm{He}$ should also indicate the general principles which the foreign law offers for an answer to the problem. Occasionally it may turn out that the foreign

824 WrGMORE, EVIDENCE $\$ 1271$ (3d ed. 1940).

83 Estate of Schluttig, 36 Cal. 2d 416, 224 P.2d 695 (1950); Rudnick v. Rudnick, 131 Cal. App. 2d 227, 280 P.2d 96 (1955) ; Estate of Leefers, 127 Cal. App. 2d 550, 274 P.2d 239 (1954); Logan v. Forster, 114 Cal. App. 2d 587, 250 P.2d 730 (1952); Pimtel v. K.N.H. Mohammed \& Bros., 107 Cal. App. 2d 328, 237 P.2d 315 (1951); Estate of Miller, 104 Cal. App. 2d 1, 230 P.2d 667 (1951) ; Hawi Mill \& Plantation Co. v. Finn, 82 Cal. App. 255, 255 Pac. 543 (1927).

$\therefore 8436$ Cal. 2d 416, 224 P.2d 695 (1950).

85 Id. at 423,224 P.2d at 700 .

86 Cf. Caz. Prob. Code $\$ \$ 259-59.2$. 
court would resort to the law of another country and its sources in order to fill the gap. ${ }^{87}$

\section{Certificates of Foreign Diplomatic or Consular Authorities}

In various foreign countries certificates of diplomatic or consular authorities concerning the law of their countries are used as proof of the foreign law. ${ }^{88}$ In the United States certificates of this nature have found a mixed reception. In Birch $v$. Birch ${ }^{89}$ the California court refused to accept a certificate of the Consul General of the Republic of China concerning the divorce law of China for the reason that the Consul General was not an offcer liaving charge of the originial Code. However, in Estate of Blak ${ }^{90}$ heavy reliance was placed on a letter of the Embassy of the Netherlands in Waslington, D.C., addressed "To Whom It May Concern." The issue was the inheritance rights of American citizens during the German occupation of the Netherlands in World War II. Weight was given to "the authority which attaches in the present international crisis to statements" Netherlands diplomatic representative. The suspicion that the inspiration

87 The Mexican Supreme Court, e.g., has frequently quoted from French treatises in cases on which the Mexican law was silent. In Rafael viuda de Bernal Maria Natalia, 74 Semanario Judicial de la Federación, 5 Época 6050 (1942), the Mexican Supreme Court referred to French text writers as one of the bases of the court's ruling that in the case of the death of a tort victim an action for damages may be brought by the person or persons who were economically dependent on the victim against the user of a dangerous instrumentality, rather than a suit by the victim's administrator, executor, or heirs.

88 See Guttermge, Comparattve Latw 51 (2d ed. 1949); Lyons, Conchutiveness of the Statentents of the Executive-Continental and Latin-American Practice, 25 BRrT. Y.B. INT'L L. 180 (1948). International agreements permitting the court of one country to address a court or the government of another country for elucidation on the law of the latter have been suggested and are partly in force. Convention on Private International Law, Bustamente Code, arts. 409-11 (1928), ratified by fifteen Latin-American countries, but not the Argentine Republic, Colombia, Mexico, Paraguay or Uruguay; see Jones, International Judicial Assistance: Procedural Chaos and a Program for Reform, 62 YAlE L.J. 515, 546 (1953); Harvard Draft Convention on Judicial Assistance, pt. VII, art. 12, 33 Ax. J. INT'L L. 112 (supp. 1939). For an earher suggestion to a similar effect see Doroghi, The Authentication of Foreigt Law in Court Procedure, 25 INT'I L. Ass'N Rep. 221 (1908). The British Foreign Law Ascertainment Act, 1861, 24 \& 25 VICr., c. 11, authorized inquiries from foreign courts concerning the written law in the foreign country provided that conventions to this effect were concluded; however, no such conventions were concluded.

89136 Cal. App. 2d 615, 289 P.2d 53 (1955).

2065 Cal. App. 2d 232, 150 P.2d 567 (1944).

91 Id. at 236, 150 P.2d at 569. Actually, the written law of the Netherland Government in exile was publicly available. This may not have been known to the court. See also $I n$ rs Estate of Krachler, 199 Ore. 448, 263 P.2d 769 (1953). Fere a diplomatic note and a letter of the National Socialist Government, purporting to show that the right of American citizens to inherit in Germany had not been infringed, were admitted into evidence, but did not influence the opinion of the court. United States v. Pink, 315 U.S. 203 (1942), is a frequently criticized case of political importance in which a certificate of a foreign governmental authority was permitted into evidence. 
of official declarations of foreign governments may not "be impartial"22 may give rise to doubts concerning the value of such certificates.

\section{The Qualifications of an Expert Witness on Foreign Law}

Under the English view knowledge acquired by study is not sufficient qualification for an expert witness on foreign law. He must have had experience as a judge or advocate in the foreign jurisdiction or have held an office or position which caused him to familiarize himself with the law to which he testifies..$^{93}$

Under the predominant American view the qualifications of expert witnesses are determined on different grounds. A person of any occupation which makes it necessary for him to give special attention to legal topics may be heard. ${ }^{94}$ The criterion for qualification is that the witness is "skilled" in the foreign law; ${ }^{95}$ he must have familiarized limself with the foreign law..$^{96}$ Standards which do not affect the qualifications of the witness but do go to the weight of his testimony include the fact he is not entitled to practice in the particular foreign country ${ }^{87}$ and his lack of first hand observation and residence there. ${ }^{98}$ The extent of the general knowledge of the witness will be considered. ${ }^{99}$ Difficulties encormtered in obtaining knowledge of the law of a particular foreign jurisdiction may cause a court to listen to an expert whose knowledge is otherwise quite limited..$^{100}$

The qualification of an expert witness on foreign law is within the "sound discretion" of the trial court, and its ruling thereon will not be disturbed without a showing of "clear abuse" of this discretion.101

92 See Sommerich \& Busch, The Expert Witness and the Proof of Foreign Law, 38 ConNEII L.Q. 125, 145 (1953).

9313 HaIsBury, Laws OF ENGLand 615 (2d ed. 1934).

942 Wigmore, Evidence $\S 564$ (3d ed. 1940); see In re Spoya's Estate, 282 P.2d 452 (Mont. 1955).

95 See, e.g., Cal. Code Civ. Proc. § 1902.

96 Estate of Schluttig, 36 Cal. 2d 416, 224 P.2d 695 (1950); In re Faber's Estate, 168 Cal. 491, 143 Pac. 737 (1914) ; McFadden v. Mitchell, 61 Cal. 148 (1882); In re Jobnson's Estate, 100 Cal. App. 2d 73, 223 P.2d 105 (1950).

07 In re Faber's Estate, sitpra note 96.

98 In re Johnson's Estate, 100 Cal. App. 2d 73, 223 P.2d 105 (1950).

99 Estate of Schluttig, 36 Cal. 2d 416, 224 P.2d 695 (1951).

100 In McFadden v. Mitchell, $61 \mathrm{Cal}$. 148 (1882), a witness was held qualified to testify on the law of the Mexican State of Sonora who, according to the Transcript on Appeal, p. 28, was acquainted with the Spanish language and "to some extent" with Mexican law and books which, according to his testimony, were recognized in Sonora as authorities. According to his testimony, there were only two or three licensed attomeys in Sonora and cases were handled in court mostly by non-lawyers who had familiarized themselves with Mexican law as he had done. Through this witness, portions from a Spanish dictionary of law were introduced into evidence.

101 Estate of Schluttig, $36 \mathrm{Cal}$. 2d 416, 224 P.2d 695 (1950); In re Johnson's Estate, 100 Cal. App. 2d 73, 223 P.2d 105 (1950). In Estate of Arbutich, 41 Cal. 2d 86, 103, 257 P.2d 433 (1953), testimony by the Yugoslavian Ambassador to the United States concerning the 
When experts contradict each other in their testimony on foreign law it is up to the trial court in its discretion whom it will believe. ${ }^{102} \mathrm{~A}$ court may disbelieve a witness on foreign law when he appears to be biased. ${ }^{103}$

\section{III}

THE PRESENT LAW:

\section{APPRAISAI AND PRACTICAI TMPIICATIONS}

We are told that the time has come when courts should take judicial notice not only of the law of sister states, but also of the law of foreign countries. ${ }^{10 t}$ Indeed, judicial notice of foreign law must be taken under the law of several states of the Union ${ }^{105}$ and may be taken under the law of several other ${ }^{108}$ although, im actual fact, foreign law must be pleaded and proved in most of these jurisdictions as if it were a fact. ${ }^{107}$ We are urged that our knowledge of foreign legal systems has improved considerably, that principles of foreign law are taught in several American universities, and that there are now well-equipped law libraries in the various parts of the country so that a judge with his ordinary judicial acumen may be well qualified to tackle problems of foreign law and to handle them with sufficient facility.

rights of American citizens under a treaty to have "their full, complete and unabridged rights of inheritance to inherit from their relatives or from their estate in Yugoslavia" was held to serve "at most to create a conflict in evidence as to the ultimate fact and is not controlling" on the issues of the case.

102 Estate of Leefers, 127 Cal. App. 2d 550, 274 P.2d 239 (1954); Estate of Miller, 104 Cal. App. 2d 1, 230 P.2d 667 (1951).

103 Cf. In re Estate of Krachler, 199 Ore. 448, 504, 263 P.2d 769, 794 (1953).

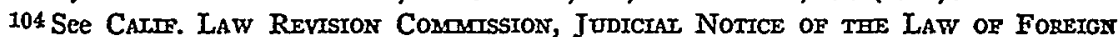
CountrRes (1957), favoring judicial notice of foreign law. See also 9 N.Y. JUD. CouncI REP. 271 (1943) favoring judicial notice but retaining the possibility that foreign law be proved by the parties; Nussbaum, The Problem of Proving Foreign Law, 50 YALE L.J. 1018 (1941). Professor Nussbaum advocates judicial notice but arrives at the conclusion that courts sbould follow any method for ascertainment of the foreign law which will most likely produce "substantial justice." See also Keefe, Landis \& Shaad, Sense and Nonsense about Judicial Notice, 2 Stan. L. Rev. 664 (1950) ; Nussbaum, Proving the Law of Foreign Countries, 3 AN. J. Comp. L. 60 (1954). Arguments opposed to taking judicial notice of foreign law are presented by Sommerich \& Busch, The Expert Witness and the Proof of Foreign Law, 38 Coranes L.Q. 125, 156 (1953).

105 See, e.g., Mass. Ams. Laws c. 233, § 70 (1956).

100 See, e.g., N.Y. Civ. Prac. Act § 344-a.

107 See Sommerich \& Busch, The Expert Witness and the Proof of Foreign Law, 38 CoRNELI L.Q. 125, 133, 144 (1953). In New York a court may take judicial notice of foreign law, but may also consider any testimony, imformation, or argument on the subject whether offered by counscl, a third party, or discovered through the court's own research. N.Y. Crv. Prac. AcT \$344-a. But when foreign law is not pleaded or the party having the burden of proof has not assisted the court in judicially learning it, the court would abuse its discretion if it took judicial notice. See Walton v. Arabian American Oil Co., 233 F.2d 541 (2d Cir. 1956) and cases cited therein.

For a similar experience in Massachusetts see Mottua, Proof of Cases In Massachusetts 211 (1951). 
The dignity of the law and the concept of justice demand, we are further told, that the judge rather than the parties is responsible for the production and investigation of foreign law. In short, under this argument, foreign law is "law" and should be treated as such by the courts. Great objection is taken to the common-law practice of treating foreign law as a fact and to the oversimplified and logically incorrect statements that foreign law is a fact.

According to Professor Morgan, ${ }^{108}$ a court which takes judicial notice takes cognizance of things which are generally known or are reasonably ascertainable as certain. In addition, statutes or the common law may authorize a judge to take "judicial notice" of matters which are not generally known or are not ascertainable as certain, but which are of a nature that little or no dispute may arise concerning the result of the investigation which the court may make. ${ }^{109}$ Within this latter definition judicial notice is said by Wigmore to be an instrument of great capacity in the hands of a compentent judge. ${ }^{110}$

Clearly foreign law does not fall under the narrow definition which Morgan gives the term judicial notice. Is foreign law capable of such ascertainment as Wignore's definition requires? Is our present knowledge of foreign legal principles such and are foreign' law books sufficiently available or likely to become available so that a court may safely take judicial notice of foreign law without being aided by the parties in its ascertainment?

Both questions must be answered in the negative. The statement in Nelson v. Bridport $t^{111}$ that the legal profession, taken as a whole, lacks that accumulated knowledge of and ready association with foreign law which is required if judicial notice of foreign law be taken, and the statement in Wickersham v. Johnston ${ }^{112}$ that a court cannot be presumed to be acquainted with or have judicial knowledge of foreign law still hold true. Occasionally one encounters the assumption that the foreign law nuust have a code or statutory section dealing squarely with the issues involved, or that a good expert witness must be able to state in the measure of a few sentences the applicable foreign law so that a judge could just as well find these code or statutory sections himself. There are very few points which lend themselves to such simple treatment. Each rule of law must be considered from the point of view of its temporal applicability, its constitutional val-

108 Morgan, Some Probiems of Proof under the ANglo-Axarican Sxstem of LitioaTION 36 (1956).

100 See, e.g., Cax. Code Crv. Proc. § 1875.

110 See generally 9 WigMore, EvIDENCE § 2566 (3d ed. 1940).

1118 Beav. 527, 50 Eng. Rep. 207 (Ch. 1845).

112104 Cal. 407, 38 Pac. 89 (1894). 
idity, its context, its qualifications whether statutory or judicial, its value when compared with other legal notions or fitted into a different legal system and its meaning under the foreign legal terminology and manner of thinking. The foreign legal thinking may be so different as to preclude the use of analogies with the domestic law, and the legal terms may lack their English equivalent. We must know whether a foreign law uses generalized rules applied to individual problems of law, or to the facts of a case; and we also inust know whether judicial interpretation or that of commentators or text writers is a part of the foreign law. In short, we must know the sources of the foreign law as they are recognized in the foreign country; we must be able to locate and evaluate these sources, wliether or not written, indexed, or digested.

There are relatively few cases in which a court receives adequate knowledge of the foreign law by inere presentation of a code or statutory section. There are very few foreign statutes, for instance, which permit a court to declare a marriage null and void or subject to annulment without further explanation concerning the meaning of the laws. A foreign statute may use the term "divorce" and mean "separation"; or it may fail to differentiate between felony and misdemeanor in the criminal law, or "intent" and "negligence" in the law of torts. Special damages might be deemed general damages, a legatee may be termed an "heir," or there may be no law of "wills."

In contrast to the law of inost sister states, foreign law is not so simple and clear that it can be quickly grasped and readily assimilated so that acquisition of its knowledge might not considerably increase the judicial burden of "knowing" the law. Frequently we find that the issue before the domestic court has not been decided in the foreign court or may not even be a likely subject for statutory treatment or litigation in the foreign country. In some cases the issue might be one of first impression in the foreign country if the question should arise at all; and in still other cases the legal problems are still open questions in the foreign countries or have found divergent solutions. ${ }^{113}$

It must be admitted that difficulties of this nature do not assume any greater proportions than those encountered in dealing with the law of sister states when we are considering the law of a country which has the same common law background as ours and which employs the English langnage. It lias been suggested from time to time that the legal systems of the Western world have many basic ideas in common and that other legal systems have certain basic rules which are generally known to us. We may, for in-

113 Under Mexican law, e.g., statutory law does not provide a final answer to the question who has a cause of action for the death of a tort victim. The solutions which are indicated in Mexican Supreme Court opinions and in treatises merely suggest the answer. See 5 Rojina Villegas, Derecho Civil Mexicano, vol. II, p.384 (1951). 
stance, know that every legal system has a basic rule that contracts must be performed, that an injury to another may cause civil legal redress, and that Communist law does not protect property interests to the same extent as does domestic law. Yet here our general knowledge ends. An American court does not know what redress a foreign law grants against nonperformance of contracts or in tort cases, nor does it know the extent to which property rights are protected under Communist laws. ${ }^{114}$

The arguments in favor of taking judicial notice of foreign law do not deal solely with the character of foreign law as law, the judicial function and the ready availability of knowledge of foreign law. They are equally concerned with the court's duty to find the truth and its desire to dispense quick and inexpensive justice. The proponents of judicial notice urge that judges, being impartial, are more likely to find the truth of the foreign law than witnesses who may be biased and that trials in which evidence on foreign law is taken are frequently smothered with technicalities and lengthened "monstrously." Similarly, it is urged that highly educated and qualified foreign law experts should not be exposed to the indignities and embarrassment which frequently mar cross-examination. It is also maintained that expert testimony is of ten so expensive ${ }^{116}$ as to make this method "unfair and asocial."117 In this comection we are told that taking judicial notice of foreign law has worked satisfactorily in many continental European countries in a manner inviting imitation. ${ }^{118}$

The initial portion of these argnments go to the question of the proper function of the court and the parties. In the eloquent langnage of Professor Morgan: ${ }^{119}$

The theory of our adversary system of litigation is that each litigant is most interested and will be most effective in seeking, discovering, and presenting the materials which will reveal the strength of his own case and the weakness of his adversary's case so that the truth will emerge to the impartial tribunal that makes the decision.

When foreign law becomes so difficult as to "invite"120 expert testimony, it becomes a controversial subject; it transcends the difficulties normally encountered in dealing with domestic law. Its presentation should be made comparable to the presentation of facts of which the court has no previous

114 Cf. Cuba R.R. v. Crosby, 222 U.S. 473 (1912) ; Estate of Kennedy, 106 Cal. App. 2d 621, 235 P.2d 837 (1951).

1159 N.Y. Judiclal Councir Rep. 271, 282 (1943).

116 The term "over-expensive" is often applied.

117 Nussbaum, Proving the Law of Foreign Countries, 3 AM. J. CoMp. L. 60, 62-63 (1954). 118 See authorities cited at note 104 supra.

119 Morgan, Some Problems of Proof under the Anglo-AMarican System of ItitigaTION 3 (1956).

120 Hawi Mill \& Plantation Co. v. Finn, 82 Cal. App. 255, 255 Pac. 543 (1927). 
knowledge and the ascertainment of which the court leaves to the parties. The Continental example should not influence our opinion. It is taken from judicial systems in which the court plays a leading part in the conduct of the trial, a part far in excess of what the legal system described by Morgan contemplates. The European experience does not strictly go to judicial notice, but rather to the right of the court to obtain knowledge of the foreign law by almost any means it pleases to employ without regard to the ordinary rules of evidence. ${ }^{121}$ It is not shared, for instance, in France ${ }^{122}$ where experimentation with various approaches to the subject over centuries has led to the rule, basically, that foreign law must be proved by the parties as a fact. ${ }^{123}$

Foreign law is scarcely a proper subject for judicial notice since the court's sources and process of thinking should be open to the parties. In

121 For a historical account of judicial methods of obtaining knowledge of foreign law in Europe see Doroghi, The Authentication of Foreign Law in Court Procedure, 25 INT'1 L. Ass'N REP. 221 (1908). A brief summary of such methods in certain civil law countries is found in Komn, Comparative Comomentaries on Private Internationat Law of Confutct of Laws 100 (1937), and in somewhat more substantial form in NIEDERER, EINFüHRUNO IN DIE ALLOEateINen LemRen des Internationalen Privatrecets 341 (1954).

There is no up to date compilation on the law and practices of foreign countries on this subject. The matter is dealt with in the codes of procedure of many foreign countries, and most treatises on international private law and procedure touch on the subject. In consulting such treatises, it should be remembered that at times they contain the author's own views rather than the law which is actually followed. Also most treatises deal merely with the formal law on the subject and do not give details concerning the actual practices employed in court. An exception to the latter rule is 1 Aramnjon, Précis de Droir International Prive 402 (3d ed. 1947), where reference is unade to some of the European foreign and comparative law institutes which furnish unsworn written opinions on foreign law to the courts of several European countries.

In a recent article the German method in which foreign law matters are handled in the courts was compared with the French method. Dölle, De l'application du droit étranger par le juge interne, Revoe Critique de Drott Internatronal Priví 233 (1955).

122 In France a party who invokes foreign law must prove it. Paris, Nov, 27, 1926, DH. 1927, 24; Paris, May 10, 1922, Clunet 1923, 540; Civ. August 2, 1893, D.P. 94. 1. 11. The judge may not apply foreign law ex officio unless it is invoked by the parties. Civ. June 12, 1894, Clunet 94, 806.

123 In the Mexican Federal District and Territories foreign written law must be proved by the parties. They may prove the foreign law by producing any creditable copy of the written law without being bound by rules like those found in most American jurisdictions according to which the copy of a foreign statute must be certified to by the keeper thereof or under which official editions of foreign statutes or editions commonly recognized in the courts of the foreign country involved are admissible as proof of the foreign written law. Thus, the Mexican Supreme Court has held that the law concerning religious marriages in Lebanon may be proved by copies of old Ottoman statutes submitted by the French High Commissioner in Syria through the French Consulate in Mexico City to the Mexican Ministry of Foreign Relations together with a statement that the statutes as submitted were the applicable law; however, the same court held that the question whether a marriage certificate issued by a Lebanese parish priest is sufficient proof of a Lebanese religious marriage must be determined by the Lebanese written law on the proof of marriage or in the absence of such statute by a sufficient showing of a custom to this effect. Statements by the French Legation in Mexico and by the French 
Arams v. Arams ${ }^{124}$ it was stated that the parties must have an opportunity to know what the court considers and "plainest principles of fair-dealing and due process" require that they be heard concerning the points of which a court may want to take judicial notice. Admittedly, the latter aim may be achieved if the court is required to give notice to the parties of what it intends to take judicial notice as suggested by the American Law Institute in its Model Code of Evidence. ${ }^{125}$

The arguments relating to the value of the testimony, bias and treatment and expense of expert witnesses also lack convincing forcefulness. When it is stated ${ }^{126}$ that expert witnesses on foreign law frequently contradict each other "hopelessly," we must consider that our system of litigation is premised on the presentation of conflicting views on domestic law by counsel and supports the idea that the best way of finding the law is by discussion on the part of persons with expert knowledge; their contradictory or supplementary statements assist the court in determining disputed questions of law. The presentation of expert testimony makes frequent advance discussion with counsel advisable in order to permit proper pleading and questioning. Such advance discussions are improper in many foreign countries as inviting bias on the part of the witness; but in such countries the court examines the witnesses. If a witness on foreigu law appears biased, the court will appraise the testimony accordingly. ${ }^{127}$ The length of the testimony would seem to be primarily controlled by the difficulty of the foreign legal problenis to be presented; contrary to a court taking judicial notice of foreigu law, the witness has done his research in advance and merely reports his findings. Time-consuming argnments concerning the admissibility of questions and answers go mostly to the witness' qualifications, materiality and relevancy, proper phrasing of questions, responsiveness of answers, and the opinion as contrasted with the hearsay character of the testimony. These are issues germane to any case in which expert witnesses are heard, but are accentuated in cases involving foreign law. This may be due to the fact that counsel invites objections to his mode of examination by the use of doubtful methods, asking the ultimate issues ${ }^{128}$ or anticipating the argument at the evidentiary stage. ${ }^{129}$

Consulate there to the effect that a certificate of this nature was legal proof of a marriage in Lebanon were held insufficient. Afif, Amado E., Semanario Judicial de la Federacion, 514 (Supp. 1934). This view has been elahorated further in the case of Ma. Teresa Catouillat de Diaz, digested in Informe rendido a la Suprema Corte de Justicia de la Nacion por su Presidento al terminar el año de 1955, Informe del Presidente de la Tercera Sala, p. 26. It should be noted that under Mexican law neither of these decisions has acquired the force of stare decisis.

124182 Misc. 328, 331, 45 N.Y.S.2d 251, 253 (Sup. Ct. 1943).

125 Moded Code of Evidence rule 804 (1942).

126 Nusshaum, Proving the Law of Foreign Countries, 3 Axr. J. Comp. L. 60 (1954).

127 Sce In re Estate of Krachler, 199 Ore. 448, 263 P.2d 769 (1953).

128 E.g., "Is this marriage void?"

129 The versatility of the witness will decide the wisdom of asking numerous individual questions or a few comprehensive ones requiring detailed, conclusive answers. The latter method, 
Finally, the claim that the production of evidence on foreign law may involve exorbitant expense to the parties overlooks the fact that judicial notice of foreign law requires that the parties draw the attention of the court to the details of foreign law which they would like considered, ${ }^{130}$ involving the appointment of experts as "referees" or "assessors" or other aides to the court ${ }^{131}$ whose costs would be charged to the parties unless public funds were made available for this purpose. When it is claimed that the lack of adequate witnesses may involve prohibitive travel expense, one wonders if in such a case the court would not authorize a commission to take evidence ${ }^{132}$ or letters rogatory. ${ }^{133}$ In addition, under certain circumstances the court is in control of the fees due expert witnesses. ${ }^{134}$ The expert's fees will, of course, frequently reflect the amount of his education, study and experience.

Most writers who criticize the present method of treating foreign law as a fact would be satisfied with any method which works "substantial justice."135 Among the most desired changes are relaxation of the rules of procedure and evidence so as to permit foreign law to be ascertained by courtappointed persons; the use of hearsay sources on foreign law such as treatises, articles in legal periodicals, and certificates issued by foreign governments or courts; and unsworn written opinions of experts.

The critics point out that when foreign law is not pleaded or proved the case may be dismissed, or the presumption that foreign law is the same as domestic law will be applied and that both methods are likely to work in-

though desirable, is hardly feasible in every situation. The expert should be familiar with the procedural rules of the court in which he testifies, particularly experts from jurisdictions which operate without the hearsay rule. A foreign law witness also should be familiar with the domestic law so that he may know the implications of the English legal language used, the problems imvolved, and how hest to present his expertise to the court.

The examination of the expert may often require considerable time and patience on the part of both the court and counsel. An apparently confused witness may merely be unfamiliar with the issues or American legal terminology; or he may employ legal concepts and language assumed to be universal, but which in fact are unknown in the local forum. Foreign methods of research and presentation may so differ that in giving his conclusions the expert is unable to give the sources upon which those conclusions are based. Courts should permit full explanation by the witness, ask clarifying questions, explain domestic law to the extent required, and be aware that hesitation and contradiction by the witness are not evidence of delaying tactics or bias but rather are indicative and a necessary consequence of the witness' thought process.

See Stern \& Morgan, Getting the Evidence 600 (1936).

130 See Annot., 23 A.L.R.2d 1431, 1448 (1952).

131 MCCorancK, Evmence 698 (1954); Note, Judicial Notice, 5 VAND. L. Rev. 296, 308 (1952).

132 See, e.g., CaI. Code Crv. Proc. \$§ 2024-2028.

133 For practical suggestions concerning open and closed commissions and letters rogatory see Consular Law Society, Letters Rogatory (Grossman ed. 1956).

184 See, e.g., CAL. Code Crv. Proc. \$ 1871.

135 See Nussbaum, The Proving of Foreign Law, 50 YaLE L.J. 1018 (1941). 
justice. But these consquences may be avoided by pleading and proving the foreign law or by the appointment of an expert witness by or at the suggestion of the court.

The argument that complicated foreign law problems lend themselves poorly to oral presentation seems justified. Often an expert witness must present several legal problems, premise them on an explanation of the legal system involved, state rules and their exceptions, refer to prior parts of his testimony, and use a terminology requiring parenthetical explanation. The direct examination of a witness may take hours in answer to one question. In such cases the court and counsel may find it preferable to follow the testimony on the basis of a memorandum submitted by the witness. The Model Expert Testimony Act $^{136}$ and the Model Code of Evidence ${ }^{137}$ point to a solution of this problem by suggesting that court-appointed experts be required to prepare under oath written reports of their inspection and examination of the foreign law, including the inferences drawn therefrom, to be filed with the court and open to inspection by the parties. This would differ slightly from the method employed in some continental European countries which does not provide for statements under oath, oral examination of the writers or cross-examination.

Whether or not a court resorts to the tool of written memoranda, expert testimony on foreign law can be greatly facilitated if the witness prepares in advance translated copies of foreign statutes, decrees and other materials on which he may rely and which may be introduced as exhibits in a suffcient number of copies for use by the court, counsel and himself. Reference to these materials facilitates understanding of the direct evidence given by the witness.

The suggestion that application of the hearsay rule may at times exclude important evidence from the determination of foreign law issues also proceeds from a sound premise. The codes and statutes of many jurisdictions, includimg California, do not provide for commentaries on foreign law, legal treatises and articles in legal periodicals as evidence of foreign law. But when these are deemed sources of law in the foreign country they should be so treated and used by domestic courts. ${ }^{138}$ In addition, books and articles on foreign law, even thougli not sources of law in the foreign country and regardless of whether written liere or abroad, should be admissible as a matter of convemence in uncontested cases and in other cases where more

136 Model EXPERT Testimony Act $\$ 6$ (1951).

137 MOdEL CODE OF EvideNCE rules 405, 406 (1942).

138 Under CAI. CoDe Crv. Proc. $\$ 1899$ unwritten law may be collected from the treatises of learned men and under $\$ 1902$ expert witnesses may testify on unwritten foreign law. In Estate of Leefers, 127 Cal. App. 2d 550, 274 P.2d 239 (1954), commentaries on German law, being a source of law in that country, were admitted into evidence. 
direct sources of the foreign law are inaccessible. ${ }^{139}$ Statutory changes of this nature can be brought about without altering the fundamental concept that foreign law is to be treated as if it were a fact. ${ }^{140}$

Finally, the present rule that the holding of a court on a specific point of foreign law is not controlling in another case ${ }^{141}$ might be corrected by permitting courts in uncontested cases to consider the evidence on foreign law given in one case as if it were given in other cases involving the same factual situation and foreign law problems. In this manner the need for repetitive testinnony ${ }^{112}$ might be avoided without resorting to the device of judicial notice.

\section{CONCLUSION}

A court required to consider foreign law in the decision of a case is able to receive adequate knowledge of the foreign law under present methods of pleading and proof or under qualified methods of judicial notice. This statement is, however, subject to substantial qualifications.

If parties have to prove foreign law, statutory amendments should authorize the use of advance memoranda which are written and sworn to by expert witnesses, filed with the court and served on the parties. In addition, removal of foreign law questions from the consideration of juries might be considered.

If judicial notice of foreign law is to be taken, the appointment of referees, assessors, or other aides to the court should be authorized and the method of their remuneration established. The parties would not be relieved of their duty to draw the foreign law to the attention of the court in adequate pleadings; but prior to the end of the hearing of the case they should be entitled to receive detailed information concerning the foreign law which the court deems applicable; also they should be entitled to submit to the court, prior to as well as after such notice, documentary evidence of written materials recognized in the foreign country as sources of its law and affidavits and testimony of expert witnesses.

Regardless of whether foreign law is subject to traditional rules of evidence or to a modified form of judicial notice, courts should consider as sources of foreign law those which are so considered in the particular for-

139 But see Birch v. Birch, 136 Cal. App. 2d 615, 289 P.2d 53 (1955), and note 78 supra.

110 Under the N.Y. Crv. PrAC. AcT $\$ 344-\mathrm{a}$ (C) textbooks, monographs, commentaries, treatises, periodicals, dictionaries, and written opinions may supply judicial knowledge of foreign law. See Sommerich \& Busch, The Expert Witness and the Proof of Foreign Law, 38 CoRnelc L.Q. 125, 154 (1953). In England textbooks and similar materials may furnish the proof of foreign law. 13 HaISBURY, LAwS OF ENGLAND 615 (2d ed. 1934).

141 Estate of Leefers, 127 Cal. App. 2d 550, 274 P.2d 239 (1954) ; Estate of Miller, 104 Cal. App. 2d 1, 230 P.2d 667 (1951).

122 See text following note 39 sufro. 
eign country, admitting textbooks, commentaries, treatises, and articles in legal periodicals as evidence of foreign law. The repetitive character of certain foreign law questions in litigation before the courts requires in uncontested cases the use of expert testimony submitted previously in cases involving identical points of foreign law.

In this manner, the argument over proof and judicial notice of foreign law is reduced from its asserted character of practical reasoning to one of legislative policy. But the legislative choice between adherence to traditional concepts and judicial notice has little effect on the obligation of the parties to take the initiative in presenting foreign law to the court. Generally speaking, the asserted advantages of judicial notice over the traditional methods of proof are largely illusory. 


\section{California Law Review}

MEACBER NATIONAI AND WESTERN CONFERENCES OF LAW REVIEWS

Published Five Times Yearly by Students of the School of Law of the University of California, Berkeley, California. Indexed in Index to Legal Periodicals and Public Affairs Information Service.

\section{BOARD OF EDITORS}

Donald M. Cahen

Editor

WALLACE R. PECK

Assistant Editor

WITIAMS R. BERKMAN Managing Editor

Geratd R. KNeCHT

ROBERT O. NAGLE

Robert A. Setigson

W. P. Clancey, Jr.

BIIIY H. HunT

Donato L. Knve

Marseate W. Krause
MARC H. MONHEDARR

Article Editor

JOE J. YASAKI

Book Review Editor

Revising Editors

JoHA E. Sparks

Stanton G. Ware

Associate Editors

HAROLD E. LANDIS

RICHARD T. LEMMMON

WITIIATM O. MTNOR

ROGER J. NICHOLS

\section{MARILYN LINDQUIST}

General Secretary

\section{Contributors}

Bruce M. Cowan

JoHr J. DUtToN

Chartes A. MtrLer

ALAN C. Nelson

WARREN G. REID

Howard A. StEGEI
Shetdon St. Ciatr

Harrete Whitaman Thayer

DAVID D. WALKIEY

HOWARD M. WEISER

RENÉ D. ZENTNER 